\title{
LETRAMENTOS, ALFABETIZAÇÃO E PRÁTICAS
} SOCIOCULTURAIS: REFLEXÕES AINDA NECESSÁRIAS

Vivemos tempos inquietantes em que recrudescem no mundo perspectivas excludentes e em que a democracia é constantemente atingida. Nesse cenário, as desigualdades educacionais mantém 110 milhões de jovens entre 15 e 24 anos, dentre os quais 59\% são mulheres, fora das culturas do escrito. ${ }^{1}$ No Brasil, embora as taxas absolutas de analfabetismo estejam em queda - $8 \%$ segundo o último censo ${ }^{2}$ - os resultados de diferentes avaliações em larga escala, como o Programme for International Student Assesment (PISA - OCDE) e a Avaliação Nacional de Alfabetização (ANA - INEP) apontam índices alarmantes. O último PISA, realizado em 2015, coloca a performance dos estudantes brasileiros de 15 anos na 59a colocação em leitura, resultado que revela estagnação desde $2000^{3}$. Na prova ANA, realizada em 2016, a qual avaliou estudantes do terceiro ano do ensino fundamental, 54,73\% dos estudantes apresentaram nível insuficiente, sendo que 34\% dos avaliados não demonstraram ser capazes de escrever de forma legível. Ainda que seja preciso analisar tais resultados com cautela, tendo em vista as concepções e os pressupostos ideológicos que marcam sua estrutura e aplicação, é certo que não podemos ignorá-los.

Com o dossiê temático Letramentos, alfabetização e práticas socioculturais: reflexões ainda necessárias, o número 11 da Pensares em Revista busca contribuir para a construção da equidade educacional e de formas de resistência aos processos de desumanização. As contribuições de pesquisadores de destaque nesse campo de estudos, não só no Brasil, mas também no exterior, reunidas nesse dossiê, permitem-nos considerar que se trata de um número especial em termos de afirmação da importância das pesquisas aplicadas à educação básica, considerando-se a diversidade de perspectivas teóricas e de práticas educacionais/formativas nele contempladas. Entendemos que os artigos aqui apresentados se complementam, dialogam entre si e até dissonam em alguns aspectos, formando um amplo painel de

\footnotetext{
${ }^{1}$ https://data.unicef.org/topic/education/literacy/

2 https://brasilemsintese.ibge.gov.br/educacao/taxa-de-analfabetismo-das-pessoas-de-15-anos-ou-mais.html ${ }^{3}$ http://download.inep.gov.br/acoes internacionais/pisa/resultados/2015/pisa2015 completo final baixa.pdf
} 
pesquisas que se espalham por diferentes regiões do país e constroem um interessante caleidoscópio.

Em Lendo pelo olho mágico, Maria Cecília Mollica, Andreia Quadrio, Hadinei Batista, Mariangela Maia e Marisa Bezerra Leal problematizam, numa perspectiva transdisciplinar, a leitura mediada pela web. Os autores discutem como o acesso à informação, ampliado ao paroxismo pela cibercultura, pode ser tanto veneno, quanto cura em tempos de pós-verdade.

No segundo artigo da coletânea, Olhares subjetivos para a alfabetização, Francisco Renato Lima e Maria Angélica Freire de Carvalho discutem a relação entre alfabetização e subjetividade, compreendendo aprendizagem da escrita como "abertura para um vir-a-ser" que impacta a identidade da criança. Sob essa perspectiva, refletem acerca de práticas pedagógicas de alfabetização.

Os dois textos seguintes abordam a formação de professores alfabetizadores. Tascieli Feltrin, Suyan Barcellos Dutra e Helenise Sangoi Antunes discutem no artigo A Formação no Pacto Nacional pela Alfabetização na ldade Certa (PNAIC) os resultados de uma proposta de autoavaliação realizada com professores formadores do PNAIC na cidade de Santa Maria RS, analisando as concepções desses sujeitos acerca do programa e buscando mapear fragilidades e potencialidades do trabalho desenvolvido na região central do Rio Grande do Sul. Já Gabriela Medela da Silva e Marcia Lisbôa Costa de Oliveira, autoras de Sobre pedras no meio do caminho: teorias de alfabetização e práticas de letramento na formação de professores, discorrem sobre a "desinvenção da alfabetização" (SOARES) e propõem um modelo de formação de professores contínuo, sistemático, situado e plural que abra espaços para a autonomia e a autoria dos alfabetizadores.

Em Formação de leitores na escola: a leitura literária em voz alta como estratégia para alfabetização, Valéria Cunha dos Santos e Ana Paula Oliveira Santana refletem sobre a experiência exitosa do projeto de letramento intitulado Show de leitura, realizado em uma escola básica da Rede Municipal de Educação de Florianópolis (SC), que incluiu estudantes do primeiro e do oitavo ano do ensino fundamental e defendem que as práticas escolares de leitura e escrita devem contribuir para a ampliação e a ressignificação das práticas de letramento dos alunos. 
Na sequência, mergulhamos no campo estético-literário. Em $A$ leitura e apropriação do literário em "A menina que não sabia ler", Márcio Araújo de Melo, Andreia Nascimento Carmo e Valdivina Telia Rosa de Melian analisam as representações da leitura e as funções do literário no texto de John Harding, enfocando a apropriação do texto literário ficcionalizada na experiência da personagem-narradora. Pensando a sala de aula, Jéssica Gonçalves da Silva, Ana Carolina da Conceição Figueiredo e Kátia Nazareth Moura de Abreu apresentam em Conto "negrinha" à luz do letramento crítico: uma experiência sobre identidade no Projeto Mais Educação uma prática pedagógica que articula conceitos advindos da Estética da Recepção aos princípios do letramento crítico.

$O$ artigo Para além do campo da visão: materiais complementares para a educação de crianças cegas e de baixa visão, de Elizabeth Motta Jacob apresenta cinco projetos de criação de material grafo tátil para crianças cegas e de baixa visão reconhecendo-as como sujeitos com plena capacidade de aprendizagem e buscando colaborar para a sua plena inclusão na sociedade.

O nono artigo, intitulado Formação escritora dos professores que ensinam a escrever: entraves, motivações e construção de práticas de produção textual, de Érica bastos da Silva, retoma o tema da formação de professores e, considerando motivações e desmotivações para escrever, destaca a importância da incorporação de práticas cotidianas de escrita pelos docentes.

As entrevistas apresentadas nesse número trazem convidados mais do que especiais, que dispensam apresentações: a professora Cecília Goulart, Bill Cope e Mary Kalantziz. Com suas densas considerações, esses três pesquisadores de destaque no campo da alfabetização e dos letramentos nos impelem a repensar conceitos e percepções.

Agradecemos às professoras Rosaura Baião, Victoria Wilson e Alessandra Fernandes pelos convites e entrevistas que adensaram as reflexões enfeixadas no dossiê e aos colegas que escolheram a Pensares em Revista como veículo de divulgação de suas pesquisas e nos permitiram cumprir a proposta do dossiê. \#UERJRESISTE

Marcia Lisbôa Costa de Oliveira Andréa Rodrigues Maria Betânia Almeida Pereira 